\title{
Natural Bioactive Compounds in the Management of Oral Diseases in Nephropathic Patients
}

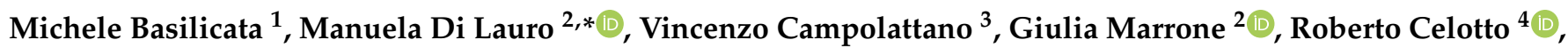 \\ Anna Paola Mitterhofer ${ }^{5}$ (i), Patrizio Bollero ${ }^{6}$, Nicola Di Daniele ${ }^{2}(\mathbb{D})$ and Annalisa Noce ${ }^{2, *}$ (i)
}

1 UOSD Special Care Dentistry, Department of Experimental Medicine and Surgery, University of Rome Tor Vergata, 00100 Rome, Italy; michele.basilicata@ptvonline.it

2 UOC of Internal Medicine-Center of Hypertension and Nephrology Unit, Department of Systems Medicine, University of Rome Tor Vergata, 00133 Rome, Italy; giulia.marrone@uniroma2.it (G.M.); didaniele@med.uniroma2.it (N.D.D.)

3 UOSD Special Care Dentistry, Department of Dentistry and Dental Prosthesis, University of Rome Tor Vergata, 00133 Rome, Italy; vincenzo.campolattano@students.uniroma2.eu

4 Department of Cardiovascular Disease, University of Rome Tor Vergata, 00133 Rome, Italy; Roberto.celotto@alumni.uniroma2.eu

5 Nephrology and Dialysis Unit, Department of Systems Medicine, University of Rome Tor Vergata, 00133 Rome, Italy; annapaola.mitter@uniroma2.it

6 UOSD Special Care Dentistry, Department of Systems Medicine, University of Rome Tor Vergata, 00100 Rome, Italy; patrizio.bollero@ptvonline.it

* Correspondence: manuela.dilauro@alumni.uniroma2.eu (M.D.L.); annalisa.noce@uniroma2.it (A.N.); Tel.: +39-06-2090-2191 (M.D.L.); +39-06-2090-2194 (A.N.)

Citation: Basilicata, M.; Di Lauro, M.; Campolattano, V.; Marrone, G.;

Celotto, R.; Mitterhofer, A.P.; Bollero, P.; Di Daniele, N.; Noce, A. Natural Bioactive Compounds in the Management of Oral Diseases in Nephropathic Patients. Int. J. Environ. Res. Public Health 2022, 19, 1665.

https://doi.org/10.3390/

ijerph19031665

Academic Editor: Paul B.

Tchounwou

Received: 7 January 2022

Accepted: 30 January 2022

Published: 31 January 2022

Publisher's Note: MDPI stays neutral with regard to jurisdictional claims in published maps and institutional affiliations.

Copyright: (C) 2022 by the authors. Licensee MDPI, Basel, Switzerland. This article is an open access article distributed under the terms and conditions of the Creative Commons Attribution (CC BY) license (https:// creativecommons.org/licenses/by/ $4.0 /)$.

\begin{abstract}
Among the chronic non-communicable degenerative diseases (CDNCDs), chronic kidney disease (CKD) represents a global public health problem. Recent studies demonstrate a mutual causeeffect relationship between CKD and oral diseases, in which the presence of one induces the onset and faster progression of the other. In particular, the oral cavity alterations more frequent in CKD patients are: chronic periodontitis diseases, bone lesions, oral infections, and oral cancer lesions. Currently, a standardized therapy for the treatment of oral diseases is lacking. For this reason, natural bioactive compounds (NBCs), characterized by several health effects, such as antioxidant, antimicrobial, antiinflammatory and anti-cancer actions, represent a new possible adjuvant therapy in the management of these pathological conditions. Among NBCs, polyphenols play a leading role due to positive modulation of oral microbiota, preventing and correcting oral dysbiosis. Moreover, these compounds exert anti-inflammatory effects, such as inhibiting the production of pro-inflammatory cytokines and the expression of cycloxigenase-2. In this light, the formulation of a new mouthwash/gel/gingival paste, with a high content of polyphenols in association with NBCs characterized by antimicrobial action, could represent a future therapy of oral disease in CKD patients.
\end{abstract}

Keywords: chronic kidney disease; chronic periodontitis diseases; polyphenols; oral microbiota; renal replacement therapy; special care dentistry

\section{Introduction}

Oral diseases are among the most widespread pathologies in the world and have rapid diffusion, becoming a real global epidemic in the last few years. Oral diseases are often associated with debilitating conditions that reduce the quality of life of patients and increase public health costs [1]. For this reason, over the years greater attention has been paid to oral preventive education, encouraging the use of good hygiene practices, and discouraging poor lifestyle habits, such as smoking, alcohol abuse and excessive consumption of sugar [2,3]. Oral health appears to be closely related to an individual's overall health [4]. In fact, the onset of an oral disease, for example caries or periodontitis, seems to represent an important risk factor for the development of several chronic non-communicable 
degenerative diseases (CDNCDs), including chronic kidney disease (CKD) [5,6]. Several studies suggest that chronic periodontitis disease (CPD) is associated with an increased risk of diabetes mellitus, arterial hypertension, atherosclerosis and neurodegenerative diseases [7-13]. The oral diseases and CKD seem to be connected to each other in a mutual cause-effect relationship, in which the presence of one induces the onset and progression of the other [14,15]. Recent epidemiological studies suggest that CKD patients appear to be more predisposed to oral diseases compared to the general population [16,17]. However, the mechanisms underlying this relationship are still poorly studied and the available data need to be confirmed by larger randomized clinical trials. The possible link between the two diseases could be represented by the alteration of the oral microbiota, a set of symbiotic bacteria in the oral cavity [18]. In fact, on the one hand, oral diseases induce an alteration of the oral microbiota, which loses its ability to protect the host from pathogenic bacteria that can enter through the buccal opening. For this reason, the alteration of oral microbiota composition could represent a risk factor for the CDNCDs onset. Therefore, these systemic diseases could induce, in turn, an alteration of the oral microbiota that is associated with an increased susceptibility to the oral disease onset $[19,20]$. Currently, one of the main topics of research is focusing on the use of strategies to prevent alterations of the oral microbiota and to safeguard the host's general health [18]. In this context, the use of natural products which, free from side effects, act by counteracting the occurrence of an oral microbiota dysbiosis, protecting from the CDNCDs, could represent a valid adjuvant strategy [21].

Natural bioactive compounds (NBCs) are biological molecules of food origin, mainly contained in plant-based food, which exert important beneficial effects in the human body $[22,23]$. The NBCs contained in plant-based food are called phytochemicals and they can be classified into different categories, such as polyphenols, carotenoids, alkaloids, phytosterols, nitrogen and organosulfur compounds [24]. Several in vitro and in vivo studies show that NBCs seem to exert important anti-inflammatory, antioxidant, antimicrobial, anticancer, cardioprotective, neuroprotective, hepatoprotective, hypoglycaemic and antihypertensive effects [25-28]. Furthermore, NBCs are able to positively modulate the oral microbiota composition [18]. Consequently, the intake of NBCs could represent a valid strategy able to counteract the onset and the progression of CDNCDs, including CKD. In this regard, the purpose of this review is to define the relationship between oral diseases and CKD and to analyze the possible role of NBCs consumption in the prevention and treatment of oral diseases. In particular, among the oral diseases, in this review we examine oral infections, dental and oral bone tissue alterations, saliva and exhaled modifications, and oral soft tissue negative changes.

\section{Research Methods}

To reach the article purpose, we selected a list of studies according to research online items of "natural bioactive compounds" and "oral disease" and "chronic kidney disease" and "periodontitis" in association with "epigallocatechin gallate" and/or "polyphenols" and/or "oral microbiota" and/or "oral inflammation" and/or "renal replacement therapy" and/or "haemodialysis" and/or "peritoneal dialysis" and/or "kidney transplant" and/or "xerostomia". The databases used were PubMed and Web of Science up to January 2022. Studies were all in English language and they were manually retrieved by the authors.

\section{Oral Health and Chronic Kidney Disease (CKD)}

Oral health of CKD patients is significantly compromised, and it is estimated that nearly $90 \%$ of them present an oral cavity alteration, including periodontal disease, impaired mineralization of the bone matrix, gingival hyperplasia and alterations of saliva secretion and composition [29]. Furthermore, CKD patients show a greater predisposition to oral infections [30]. These changes may be related both to CKD itself and to the effect of renal replacement therapy (RRT) [31,32]. At the same time, poor oral hygiene care can favor and exacerbate the chronic low-grade inflammatory state, typical of CKD [33]. In order to prevent oral diseases in CKD patients, it is necessary to develop specific oral hygiene 
strategies. Moreover, it has been shown that the presence of a lesion or other pathological processes of the oral cavity, if not treated, can accelerate the progression or induce the onset of CKD comorbidities [31]. Oral diseases and CKD appear to have a bidirectional correlation with a reciprocal cause-effect relationship (Figure 1) [34].

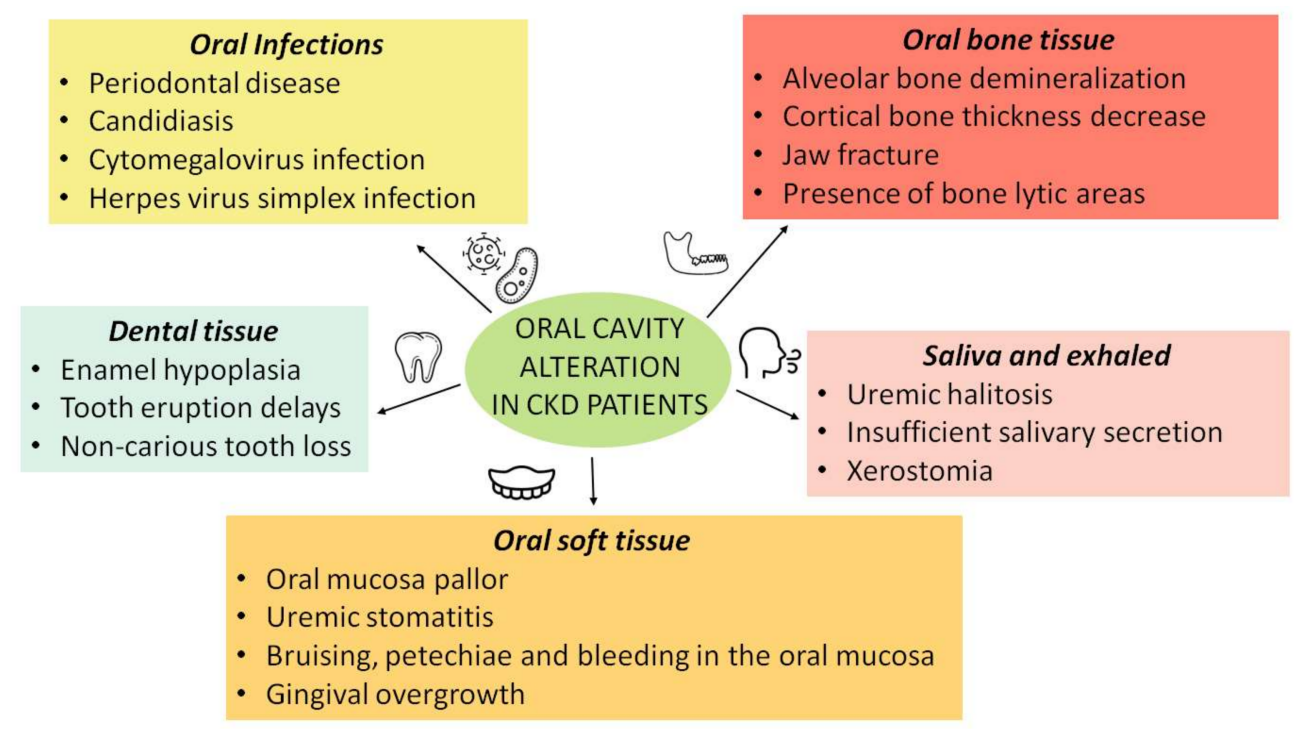

Figure 1. Oral cavity alteration in chromic kidney disease (CKD) patients.

\subsection{Effects of CKD Comorbidities on Oral Health}

Some of the main uremic comorbidities may represent important risk factors for the oral alterations onset, including uremic toxins accumulation, normochromic and normocytic anemia, water-electrolyte imbalance, calcium-phosphorus metabolism alteration and possible concomitant malnutrition [35].

\subsubsection{Saliva and Exhaled Alteration}

Nearly one third of end stage renal disease (ESRD) patients show a condition known as uremic halitosis [36]. In fact, the loss of renal function, especially in more advanced CKD stages, induces urea accumulation both in saliva and serum. In the oral cavity, excess urea is converted into ammonia by the urease-positive microbial flora, responsible for the typical halitosis of ESRD patients [35]. Several studies have shown a direct correlation between the serum accumulation of urea, and other uremic toxins, with the present of ammonia in CKD patients' exhalation [37]. The ammonia accumulation in the oral cavity is responsible for the reduction in salivary flow and for the mouth dry, phenomena usually observed in ESRD patients [36]. Furthermore, this condition leads to the perception of a metallic and unpleasant taste following the ingestion of food, which induces the patient to reduce caloric and protein intake, contributing to the development of protein-energy wasting (PEW) syndrome, typical of CKD patients [38]. In fact, CKD patients present often this syndrome which is characterized by muscle hypercatabolism, chronic inflammatory state and metabolic acidosis [38-40]. This condition causes non-intentional reduction of body weight and loss of muscle mass, with a concomitant increase of pro-inflammatory cytokines, such as tumor necrosis factor (TNF)- $\alpha$ and interleukin (IL)-6, partly responsible for the onset of a chronic inflammatory state [41]. In addition, the pro-inflammatory state tends to decrease the albumin in the circulation, exacerbating the state of malnutrition [42]. The establishment and the worsening of PEW syndrome increase the hospitalization rate and all-causes mortality of CKD patients [38]. The loss of muscle mass leads to a further increase in urea levels, in the blood and the saliva, enhancing uremic halitosis and leading to the development of a vicious circle [35]. In addition to serum urea high level, other factors probably implicated in the onset of uremic halitosis are the increase in the serum phosphorus concentration and the alteration of salivary $\mathrm{pH}$ [43-45]. Uremic halitosis 
can also be associated with a burning sensation on the lips and tongue by neuropathic origin [46] or even with a sensation of an enlarged tongue [44].

\subsubsection{Oral Soft Tissue Alterations}

Other oral abnormalities often found in CKD patients concern oral soft tissue. Often CKD patients in more advanced stages present a normochromic and normocytic anemia, mainly due to a deficit in the production of erythropoietin and to a reduction in the half-life of red blood cells. The anemia is at the basis of the characteristic pallor of the mucous membranes which is often observed in CKD patients [47].

Moreover, a clinical condition known as uremic stomatitis may be encountered in ESRD patients. This is an oral complication of unknown etiology which is relatively uncommon $[43,46,48]$. Clinically, uremic stomatitis is characterized by the presence of erythematous lesions in the oral cavity, which can be localized or generalized. These lesions are covered with a pseudomembranous exudate that can be removed, leaving an intact or ulcerated mucosa [45]. Uremic stomatitis is determined by lesions that often heal spontaneously, but in order to promote their healing, the treatment with a mildly acidic rinse, such as $10 \%$ hydrogen peroxide, appears to be effective [43].

\subsubsection{Dental Tissue Alterations}

In the presence of $\mathrm{CKD}$, it is possible to observe anomalies in the teeth. A sign frequently encountered in CKD patients is enamel hypoplasia. It mainly associated with the alteration of calcium-phosphorus metabolism [48]. Hypoplasia of the dental enamel is a pathological condition characterized by the lack of development of the dental enamel, which therefore presents a quantitative deficit and a reduced thickness. A patient suffering from enamel hypoplasia experiences problems not only of an aesthetic nature, but this pathological condition can also represent an important risk factor for the development of more serious oral diseases [47]. Dental enamel health is deeply affected by a patient's nutritional status. Vitamin D, calcium, vitamin A deficiency and the present of PEW have been associated with enamel hypoplasia, conditions which also lead to increased susceptibility to tooth decay [49]. Enamel hypoplasia is a condition that is often found in CKD pediatric patients. In fact, a prolonged deficiency of vitamin A, vitamin D and calcium during the development of the teeth can lead to an enamel atrophy and a dentin defective apposition and calcification [49]. In particular, Bawden et al. hypothesized that a hypovitaminosis D leads to an inadequate transport of calcium, useful for the dental tissues' development [50]. Vitamin D deficiency affects the structure of the teeth, and it delays their physiological eruption. In the presence of vitamin D deficiency, the teeth are microscopically characterized by an extended layer of predentin, by the presence of interglobular dentin, and by enamel imbalance formation [51]. In CKD adult patients, on the other hand, hypovitaminosis D can lead to the narrowing or the calcification of the pulp chamber [35].

Currently, there is no unambiguous consensus regarding the increased risk of developing dental caries in CKD patients [44]. A potential antibacterial effect was, in fact, attributed to the increase in salivary $\mathrm{pH}$, due to the hydrolyzation of urea by saliva, suggesting its protective action against caries [47]. In contrast, non-carious tooth loss is more prevalent in CKD patients than in the general population. This loss can be induced by uremic gastritis and by gastro-esophageal reflux, which often occur in ESRD patients, and which can be responsible for tooth erosion [35].

\subsubsection{Oral Bone Tissue Alteration}

In CKD patients, further alterations of the oral cavity are linked to the alteration of calcium-phosphorus metabolism, vitamin D abnormal metabolism and compensatory hyperplasia of parathyroid, causing the development of CKD-mineral and bone disorder (CKD-MBD) [35]. At the oral cavity level, CKD-MBD is characterized by demineralization of the alveolar bone, reduction of trabecular bone, decrease of cortical bone thickness, 
metastatic calcifications of soft tissues, fibrocystic lesions, lytic bone areas, fracture of the jaw (spontaneous or after dental procedures), by abnormal bone healing after an extraction and, sometimes, by tooth mobility secondary to bone substance loss [47].

\subsection{Effects of Renal Replacement Therapy on Oral Health}

In addition to oral changes due to comorbidities related to CKD and CKD itself, other anomalies in the oral cavity can be induced by RRTs, such as dialysis (hemodialysis-HD and peritoneal dialysis) and kidney transplant.

\subsubsection{Oral Alteration in Dialysis Patients}

In HD patients, the bleeding of the oral mucosa is frequent. It may be due to CKD itself, such as platelet alteration functions and normochromic and normocytic anemia [52,53], or HD treatment. The latter can induce or exacerbate the condition of thrombocytopenia caused by mechanical damage and heparin use during HD procedure. For these reasons, HD predisposes patients to bruising, petechiae and bleeding in the oral mucosa [45].

Furthermore, due to the reduced water intake and polypharmacy, a condition of xerostomia is often found in HD and peritoneal dialysis patients [44]. Xerostomia is characterized by dryness of the oral cavity resulting from insufficient salivary secretion or from a complete lack of saliva. Based on its pathogenesis, it is classified as true xerostomia (primary xerostomia), resulting from malfunction of the salivary glands, or pseudo-xerostomia, also known as symptomatic xerostomia (xerostomia spuria), during which the patient has a subjective impression of a dry mouth despite the normal function of the salivary glands [54]. Xerostomia can affect oral function and can compromise the patient's well-being. In fact, salivary secretions are vital for oral health, as they are involved in mechanical cleaning with a protective function. Hyposalivation can also increase the risk of oral infections, such as candidiasis, and the patient's susceptibility to dental caries, periodontal disease and tooth loss [44].

In HD patients, epidemiological studies show that oral hygiene is usually poor so the deposits of tartar and plaque can be increased [35].

Currently, few data are present in literature about the relationship between peritoneal dialysis and CPD.

\subsubsection{Oral Alteration in Renal Transplant Patients}

Renal transplant patients often undergo immunosuppressive therapy which makes them more susceptible to infections and to the development of malignancies [55]. Renal transplant patients are, therefore, more vulnerable to fungal infections, including Candida albicans, which can induce lesions of the oral mucosa and the perioral [35]. One of the main complications of fungal infections is angular cheilitis, which is an inflammatory disorder that affects the corners of the mouth. Angular cheilitis is observed in more than $4 \%$ of renal transplant patients. Other forms of candidiasis have been reported in renal transplant patients, including pseudomembranous $(1.9 \%)$, erythematous $(3.8 \%)$, chronic atrophic_-also called prosthetic stomatitis (3.8\%) [35].

Among viral infections, cytomegalovirus (CMV) and herpes virus simplex (HSV) are frequently associated with the use of immunosuppressive therapy. In particular, the ulceration of the oral mucosa is often associated with CMV infection, with a preference for the lateral edges of the tongue [55].

In addition, a secondary effect of cyclosporine therapy, known as gingival overgrowth (GO), may be observed in renal transplant patients. GO secondary to immunosuppressive therapy is the most studied oral alteration in renal transplant patients. It has been observed that if patients are treated with a combination of cyclosporine and nifedipine, the prevalence of GO increases to $50 \%$. A study by Marshall et al. highlighted how this effect occurs within 3 months from the beginning of this pharmacological treatment. This overgrowth, which normally begins at the interdental papillae, is most common in the anterior segments of the mouth and on the labial surfaces of the teeth [56]. GO does not seem to have a 
predilection for the maxilla or the mandible [35]. Given the numerous side effects of cyclosporine affecting the oral cavity, other therapeutic alternatives have been developed. In fact, tacrolimus, rapamycin, and mycophenolate mofetil are used to replace cyclosporine. These therapeutic alternatives are characterized by a GO decrease. However, these drugs are more expensive, and all their side effects are not yet known. For these reasons, in many cases, cyclosporine remains the first immunosuppressive therapeutic option [35].

Cases of malignant lesions, such as squamous-cell carcinoma and Kaposi sarcoma, which could develop in GO areas induced by cyclosporine, have also been described in renal transplant patients. The increased risk of malignant lesions in the oral cavity in renal transplant patients is a direct consequence of long-term immunosuppressive therapy [44].

\subsection{Periodontal Disease and $C K D$}

CPD is an infectious disease caused by Gram-negative bacteria responsible for destruction of the supporting tissues of the teeth. The presence of these bacteria in the subgingival biofilm causes the release of proteolytic enzymes, capable of degrading the gingival tissue [57]. Periodontal pathogens not only induce inflammation and local destruction of oral tissues, but they are also associated with the onset of a systemic inflammatory state. An interesting study conducted on 359 CKD patients highlighted how non-surgical periodontal treatment induced a reduction in systemic inflammation, monitored by pro-inflammatory cytokines [58]. Therefore, it is hypothesized that the treatment of CPD in CKD patients may have a positive effect on oxidative stress (OS) and on systemic inflammatory state [16,59]. These last represent prognostic factors associated with more sudden worsening of residual renal function [60]. Therefore, it is plausible to hypothesize that CPD may represent an important risk factor for the onset and the progression of CKD [58]. Furthermore, the mortality rate of CKD patients seems to be profoundly increased in the presence of periodontitis [16].

The microbial complexes in the subgingival biofilm during CPD were classified according to their pathogenic potential into five groups: red, green, orange, yellow and purple [61]. Notably, the red group, which is composed of Tannerella forsythia, Treponema denticola, and Porphyromonas gingivalis, has been identified as the major and severe cause of CPD [61]. These phenomena seem to be related to the dysbiosis of the oral microbiota characterized by increased microbial diversity and by the presence of anaerobic bacterial species [62,63], highlighting new potential pathogenic species associated with CPD, such as Filifactor alocis, Fretibacterium fastidiosum and Treponema vincentii [64,65]. Furthermore, red complex bacteria and Candida albicans are present more frequently in CKD patients with CPD than in healthy individuals [58]. Therefore, it is essential to perform a periodic examination of the oral cavity in CKD patients to allow an early diagnosis and a prompt treatment of CPD [57].

Some of these periodontal-pathogenic microorganisms play a direct action on the progression of CKD. In particular, periodontal bacteria can compromise the kidney healthiness through several mechanisms: (i) indirect, such as the systemic bacteremia, which develops from gingival ulcerations and which allows pathogenic microorganisms to enter the bloodstream, and the release of pro-inflammatory cytokines, responsible for tissue destruction; (ii) direct, such as the destruction of the alveolar bone [59].

During periodontal inflammation, the interaction between the pathogenic microorganism and the immune system leads to the secretion of pro-inflammatory cytokines, which in turn attract other cells of the immune system, more specific against the recognized pathogen, amplifying the inflammatory state. Cytokines are secreted by different cell groups and can act both as inflammation amplifiers and as responsible of direct tissue destruction. Inflammatory cytokines enhance vascular permeability, which in turn can increase bacteremia and stimulate fibroblasts and inflammatory cells, inducing the release of other cytokines. During inflammation, the expression of endothelial adhesion molecules also increases, such as the intercellular adhesion molecule (ICAM)-1 and the vascular cell adhesion molecule (VCAM)-1, E-selectin and chemokines (monocyte chemoattractant protein-1 and IL-8) [66,67]. 
Among other typical features associated with CPD, OS plays a pivotal role in the relationship between periodontitis and CKD. In CPD, reactive oxygen species (ROS) are an important primary defense system, and they are produced by inflammatory cells [68]. It is plausible that OS has a significant impact on local periodontal lesions. The effects of OS on systemic inflammation have been demonstrated by several research groups. For example, tissue levels of 8-hydroxydeoxyguanosine (8-OHdG), an OS marker, are increased in multiple organs, such as liver, heart, kidneys, and brain in an animal model of periodontal inflammation [69]. Therefore, it is hypothesized that the balance between pro-oxidant and antioxidant species is associated with the onset, the severity and the progression of CPD and its systemic complications [59].

\section{Use of Natural Bioactive Compounds (NBCs) to Prevent and Treat Oral Diseases in CKD Patients}

Numerous studies suggest that NBCs exert important beneficial effects in safeguarding oral cavity health [18]. The NBCs are organic compounds present in nature and they are able to exert healthy actions. These compounds are contained in numerous food sources, mostly in plant-based ones, such as fruit and vegetables [28]. Recently, foods rich in NBCs have been characterized for their beneficial proprieties and for this reason they are called "functional foods". To date, more than 5000 NBCs have been isolated from plant-based foods and they have been classified according to their chemical structure in phenolics, carotenoids, alkaloids, phytosterols, nitrogen-containing compounds, and organosulfur compounds [70]. Phenolic compounds, especially polyphenols, are undoubtedly the most studied. The beneficial effects exerted in the oral cavity can be displayed both using NBCbased products, commonly employed in oral hygienic practice, such as toothpastes and mouthwashes, and through the NBCs oral administration, as food or as dietary supplements. In the first case, NBCs seem to exert a direct action through contact with the cells and tissues of the oral cavity, displaying their effects without the loss of efficacy due to a lack of systemic distribution or to the reduction of their bioavailability, which is observed when the NBCs are assumed through foods or oral food supplements [71,72] (Figure 2).

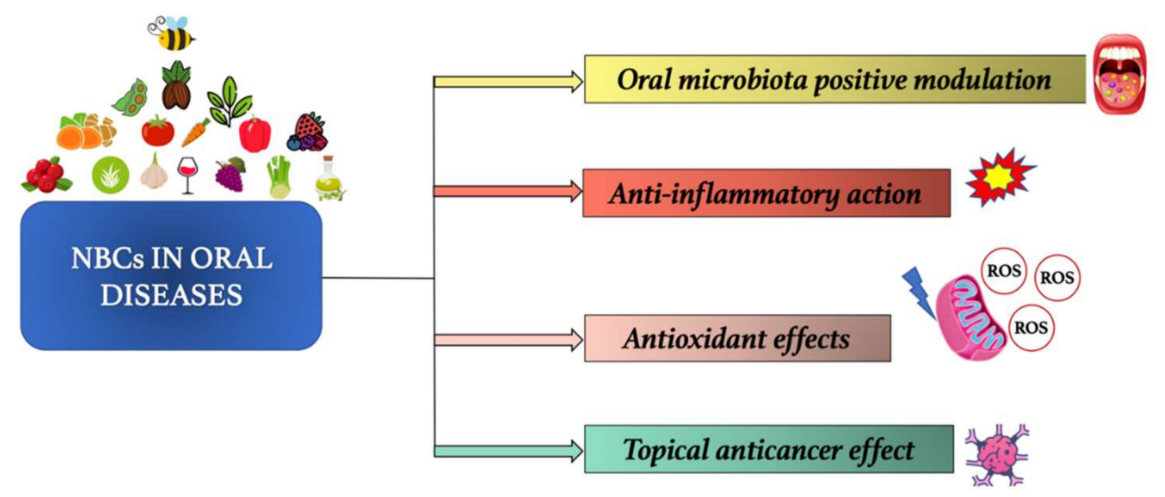

Figure 2. Natural bioactive compounds (NBCs) main actions in oral diseases.

The NBCs act thanks to various mechanisms in countering the oral diseases onset and progression: (i) they can act by the oral microbiota positive modulation and thus, preventing the onset of dysbiosis, closely related to the increase in oral infections susceptibility; (ii) they are able to exert an anti-inflammatory action, preventing/treating inflammatory oral diseases, such as periodontal disease; (iii) they perform antioxidant effects, preventing the OS. The latter impairs the immune defences, making the host more susceptible to oral infectious diseases, such as gingivitis by herpes virus and candida; (iv) they exert also a topical anticancer effect on oral cavity cells and tissues, reducing the onset and progression of cancer typical of the oral cavity, such as oral squamous cell carcinoma (Figure 3). 


\begin{tabular}{|c|c|c|}
\hline \multicolumn{3}{|c|}{ ORAL MICROBIOTA MODULATION } \\
\hline Garlic & Periodontal pathogens & $\begin{array}{l}\text { Bacterial growth } \\
\text { Protease activity }\end{array}$ \\
\hline Green tea & Dental caries and plaque & $\begin{array}{l}\text { Bacterial proliferation } \\
\text { Biofilm formation }\end{array}$ \\
\hline Aloe vera & $\begin{array}{l}\text { Periodontal disease } \\
\text { Gingivitis }\end{array}$ & $\begin{array}{l}\text { Antibacterial and anti-plaque action } \\
\text { Gingival anti-inflammatory effects }\end{array}$ \\
\hline \multicolumn{3}{|c|}{ ANTI-INFLAMMATORY EFFECTS } \\
\hline Cranberry 80 & Periodontal disease & $\begin{array}{l}\text { 1. Pro-inflammatory citokines (IL-6, IL-8, TNFa) } \\
\text { (1 MMPs }\end{array}$ \\
\hline$C_{[91-93]}$ & Periodontal disease & $\begin{array}{l}\text { 4. Pro-inflammatory citokines } \\
4 \text { Prostaglandin } \mathrm{D}_{2}\end{array}$ \\
\hline Quercetin & Oral disease & $\begin{array}{l}\text { NF-kB } \\
\text { / AKT/ AMPK/mTOR }\end{array}$ \\
\hline Curcumin & Gingivitis & $\begin{array}{l}\text { Pro-inflammatory citokines } \\
\text { (Chemokines }\end{array}$ \\
\hline \multicolumn{3}{|c|}{ ANTIOXIDANT EFFECTS } \\
\hline Green tea & Periodontal disease & \& ROS generation \\
\hline soy 8 & Periodontal disease & $\begin{array}{l}\text { NOS } \\
\text { Protection from mitochondrial damages }\end{array}$ \\
\hline Tomatoes & $\begin{array}{c}\text { Periodontal disease } \\
\text { Gingivitis }\end{array}$ & $\uparrow$ Physiological antioxidant defences \\
\hline$[106,107]$ & Periodontal disease & $\begin{array}{l}1 \text { Antioxidant and anti-inflammatory } \\
\text { action }\end{array}$ \\
\hline \multicolumn{3}{|c|}{ ANTICANCER EFFECTS } \\
\hline $\begin{array}{l}W_{2} \\
\text { [108-no] }\end{array}$ & $\begin{array}{l}\text { Oral squamos cell } \\
\text { carcinoma }\end{array}$ & $\begin{array}{l}\text { Sustemic mechanisms: } \\
\text { Chronic inflammation and OS } \\
\text { Tepical mechanisms: } \\
\text { Cellular apoptosis } \\
\text { Growth, invasion and metastasis }\end{array}$ \\
\hline Green tea & $\begin{array}{l}\text { Oral cancer cell lines } \\
\mathrm{H}_{400} \text { and } \mathrm{H}_{357}\end{array}$ & $\begin{array}{l}\text { Migration capacity } \\
\text { Nephrotoxic effect of cisplatin }\end{array}$ \\
\hline \multicolumn{3}{|c|}{ OTHER BENEFICIAL EFFECTS } \\
\hline Ginko biloba & Periodontal disease & $\begin{array}{l}\text { Alveolar bone resorption } \\
\text { Bone alkaline phosphate synthesis }\end{array}$ \\
\hline Rhinacanthus nasutus $\mathrm{L}$. & Periodontal disease & Osteoporotic process \\
\hline Propolis $\mathbf{J}$ & Periodontal disease & ( Alveolar bone demineralization \\
\hline
\end{tabular}

Figure 3. Possible beneficial effects of natural bioactive compounds on oral diseases in chronic kidney disease patients. Abbreviations: AKT, protein kinase B; AMPK, AMP-activated protein kinase; IL-6, interleukin-6; IL-8, interleukin-8; MMPs, matrix metalloproteinases; mTOR, mammalian target of rapamycin; NF- $\kappa \mathrm{B}$, nuclear factor- $\mathrm{kB}$; NOS, nitric oxide synthase; OS, oxidative stress; ROS, reactive oxygen species; TNF- $\alpha$, tumor necrosis factor $\alpha$.

\subsection{Modulation of the Oral Microbiota}

Several studies highlight how NBCs are able to positively modulate the oral microbiota, preventing oral dysbiosis, usually observed in CKD patients (Figure 3) [73].

Garlic has well-known antimicrobial and antifungal proprieties, thanks to its content in allicin, an organosulfur compound that is able to inhibit the proliferation of various oral pathogens, including Porphyromonas gingivalis and Aggregatibacter actinomycetemcomitans [74]. In particular, allicin appears to inhibit the bacterial growth and protease activity of periodontal pathogens, suggesting how the extracts of Allium sativum could represent a valid therapeutic strategy in the management of oral infections [75].

Green tea extract, rich in polyphenols, seems to counteract the proliferation of the most common bacteria that induce dental caries, including Streptococcus mutans and Streptococcus 
salivarius [76]. Green tea extract exerts a bactericidal effect through various mechanisms, such as damage and lysis of bacterial cell membranes, inhibition of ATP-synthase and of bacterial energy metabolism and prevention of the microorganism adhesion on the oral surface. All these mechanisms ensure that pathogenic bacterium is no longer able to colonize the host $[77,78]$.

The catechins and epigallocatechin of cocoa (Theobroma cacao) seem to have important anti-cariogenic properties, inhibiting the biofilm formation and proliferation of the main oral pathogens that induce caries and plaque, such as Streptococcus mutans and Streptococcus sanguinis $[79,80]$. In particular, cocoa polyphenols inhibit the bacterial production of sucrose by enzyme dextransucrase, responsible for the formation of plaque [81].

Aloe vera is a further powerful oral antimicrobial and antiviral agent, thanks to the presence of an active compound named aloin, anthaquinone compound [82]. Aloe vera would seem to exert anti-plaque and gingival anti-inflammatory effects similar to that of chlorhexidine, a broad-spectrum antibacterial agent, but totally free of side effects [83]. In fact, aloe vera exerts its anti-inflammatory proprieties inhibiting cyclooxygenase (COX) pathway and reducing prostaglandin E2 production from arachidonic acid [84].

\subsection{Anti-Inflammatory Effects}

NBCs exert important anti-inflammatory effects in the oral cavity [85]. In CKD patients, NBCs could be used in the prevention or in the treatment of inflammatory oral diseases (Figure 2).

The cranberry proanthocyanins seem to exert anti-inflammatory effects in the oral cavity, through different mechanisms. They appear to be able to inhibit the production of pro-inflammatory cytokines (such as IL-6, IL-8 and TNF- $\alpha$ ) by gingival fibroblasts, the main cells mediating the inflammatory response of the periodontal tissues [86]. Furthermore, in vitro studies suggest that cranberry proanthocyanins inhibit the expression of COX-2, responsible for the prostaglandin E2 production (important inflammatory mediator) [87]. Finally, cranberry proanthocyanins inhibit both the activity and the synthesis of matrix metalloproteinases (MMPs), enzymes produced by inflammatory cells in response to periodontopathogens. Moreover, these enzymes are involved in the degradation of periodontal tissue and alveolar bone resorption, phenomena observed in periodontal disease [88]. For this purpose, the use of cranberry-based toothpaste or oral supplements could represent a valid treatment to counteract inflammatory oral diseases, such as periodontitis [89].

Another NBC with proven anti-inflammatory effects is luteolin, a flavone contained mainly in carrots, fennel, and pepper. In vitro and in vivo studies have shown that luteolin inhibits the production of IL- 6 , TNF- $\alpha$ and prostaglandin D2 by gingival fibroblasts, if they are stimulated by periodontopathogens, and it inhibits the expression of COX-2 [90-92].

Furthermore, in vitro studies show that quercetin, a flavonoid in grapes, apples, and onions, inhibits the synthesis of TNF- $\alpha$ by oral macrophages through the nuclear factor- $\mathrm{kB}$ $(\mathrm{NF}-\mathrm{kB})$ pathway suppression $[93,94]$. Moreover, quercetin seems to reduce the IL-1 $\beta$, IL-6, IL- 8 and TNF- $\alpha$ production and the COX-2 activity, suppressing the AKT/AMPK/mTOR pathway, in oral mucosal keratinocytes. These beneficial actions demonstrate quercetin's protective role in countering inflammatory oral diseases [95].

Curcumin, the main polyphenol in turmeric, is often used as a natural remedy in the treatment of periodontal diseases due to its anti-inflammatory power, therefore in the market there are several curcumin-based toothpastes and mouthwashes [96]. Curcumin appears to reduce the release of inflammatory prostaglandins, IL- $1 \beta$ and chemokine ligand 28 (CCL28) levels, in the gingival crevicular fluid in patients with gingivitis, after topical administration of a curcumin-based gel [97].

\subsection{Antioxidant Effects}

Among the beneficial effects of NBCs there are antioxidant actions, that are exerted both by stimulating the natural antioxidant defence mechanisms and by directly neutralizing the pro-oxidant species. Several studies have highlighted how NBCs counteract 
ROS overproduction, which can be observed in patients with periodontitis and with CKD (Figure 2) [98,99].

Epigallocatechin gallate (EGCG), the main polyphenol in green tea, seems to have an important antioxidant action, countering the ROS generation and exerting a powerful scavenger of free radicals in periodontitis [100]. At the same time, ECGC stimulates the antioxidant defences. A study conducted by Hrishi et al. has highlighted how the daily use of a green tea-based toothpaste should increase the activity of glutathione-S-transferase in the gingival crevicular fluid of patients with CPD [101].

Genistein, the main isoflavone in soy, appears to be a powerful antioxidant and an inhibitor of nitric oxide synthesis. A study has shown how injections of $20 \mathrm{mg} / \mathrm{kg}$ of body weight of genistein, in mouse models with periodontitis, protect cells from mitochondrial damage and the ROS accumulation, as well as reduce the inflammatory cytokine levels in periodontal tissue [102].

Another NBC with antioxidant action useful in countering the progression of periodontal disease is lycopene, a carotenoid mainly contained in tomatoes. In vivo studies showed how oral lycopene supplementation stimulates the physiological antioxidant defences. Moreover, these studies highlight its possible use as adjuvant treatment in the management of periodontal disease and of gingivitis [103,104].

Numerous animal studies suggest that resveratrol, the main polyphenol of red wine, is able to counteract the onset and the progression of periodontal disease, thanks to its powerful antioxidant, as well as anti-inflammatory actions [105]. In particular, resveratrol seems to stimulate antioxidant enzymes activity, such as superoxide dismutase, catalase, and peroxidase [106].

\subsection{Anticancer Effects}

Among the NBCs, polyphenols seem to have an important anticancer action, both through systemic mechanisms, such as the OS and chronic inflammation reduction, and through topical mechanisms, such as the induction of cellular apoptosis and the inhibition of growth, invasion, and metastasis of cancer cells $[107,108]$. Therefore, the polyphenols could be a new potential adjuvant treatment for some types of cancer, including oral squamous cell carcinoma (Figure 2) [109].

A recent in vitro study investigated the possible effect of green tea EGCG in slowing growth of cancer cells, in particular of oral cancer cell lines H400 and H357. The authors pointed out how cell growth and migration capacity of both cell lines were deeply slowed down after treatment with EGCG extracts [110]. Interestingly, it has been shown that the oral intake of green tea EGCG seems to be able to reduce the nephrotoxic effect due to the use of cisplatin, one of the most common chemotherapy drugs used in the treatment of bladder, neck, lung, and testicular cancer [111]. In fact, cisplatin seems to act specifically in the kidney, stimulating mitochondrial OS, exerting nephrotoxic effects, which can lead to acute kidney damage or CKD worsening [112-114]. Therefore, the use of green tea polyphenols through both systemic and topical administration could represent a valid adjuvant strategy to counteract the progression of oral cancers and at the same time protect against the nephrotoxicity of common anticancer drugs.

\subsection{Other Beneficial Effects}

NBCs are able to slow down the alveolar bone resorption process that can be observed in patients with CKD-MBD, as demonstrated by several studies (Figure 2) [115].

The local administration of extracts of Ginkgo biloba leaves, an ancient tree belonging to the Ginkgoaceae family, seems to inhibit the alveolar bone loss that is observed in periodontitis [116]. In fact, these extracts stimulate osteoblasts to produce bone alkaline phosphatase, an enzyme that plays a key role in the bone mineralization process [117].

Rhinacanthus nasutus L., a natural herb of Chinese origin rich in carotenoids, appears to exert an anticlastogenic action, by inhibiting the receptor activator of nuclear factor-kB ligand (RANKL) action, a factor produced by osteoblasts under various stimuli, including 
inflammatory ones, responsible for the differentiation and the activation of osteoclasts [118]. These data suggest how this plant could be used in the treatment of osteoporotic process, even to the alveolar bone.

Propolis, a natural resin produced by bees, seems to protect the alveolar bone tissue from demineralization induced by periodontitis [119]. This NBC inhibits the production and the activation of osteoclasts, and it stimulates the production and the activation of osteoblasts in the alveolar bone [120].

\section{Conclusions}

Extensive scientific evidence suggest that oral health is closely related to individual general health. In fact, the presence of an oral disease could lead to an increased risk of CDNCDs onset, such as CKD. A mutual cause-effect relationship exists between oral disease and CKD and the possible link is represented by systemic chronic inflammation and oral microbiota dysbiosis. In this context, the use of NBCs capable of exercising, through different mechanisms, important beneficial effects in the prevention and in the treatment of oral diseases represents a valid strategy to counteract the onset and progression of CKD and its comorbidities, as suggested by several scientific evidence collected in this review.

In this perspective, the formulation of a new mouthwash/gel/gingival paste with a high content of polyphenols derived from the minor polar compounds of extra virgin olive oil [121], in association with NBCs with antimicrobial action, such as tannins from Castanea sativa [122], could represent a new therapeutic tool for oral diseases in CKD patients. In particular, for uremic stomatitis, a gel based on aloe vera and clove oil could be formulated. The former would appear to reduce pain and inflammation, while the latter is able to relieve pain.

Author Contributions: Conceptualization, M.B. and A.N.; methodology, M.D.L. and V.C.; writingoriginal draft preparation, M.B., M.D.L., V.C., G.M., R.C. and A.N.; writing-review and editing, A.P.M., P.B., N.D.D. and A.N.; visualization, M.D.L. and G.M.; All authors have read and agreed to the published version of the manuscript.

Funding: This research received no external funding.

Institutional Review Board Statement: Not applicable.

Informed Consent Statement: Not applicable.

Data Availability Statement: Not applicable.

Acknowledgments: We are in debt with Giada Iafrate for English language revision. We thank Lazio Region and ARSIAL (Regional Agency for Development and Innovation of Lazio Agriculture) for the research project called "Food culture well-being and natural cuisine".

Conflicts of Interest: The authors declare no conflict of interest.

$\begin{array}{ll}\text { Abbreviations } \\ \text { 8-OHdG } & \text { 8-hydroxydeoxyguanosine } \\ \text { CCL28 } & \text { Chemokine ligand 28 } \\ \text { CDNCDs } & \text { Chronic non-communicable degenerative diseases } \\ \text { CKD } & \text { Chronic kidney disease } \\ \text { CKD-MBD } & \text { Chronic kidney disease- mineral and bone disorder } \\ \text { CMV } & \text { Cytomegalovirus } \\ \text { COX } & \text { Cyclooxygenase } \\ \text { CPD } & \text { Chronic periodontitis disease } \\ \text { EGCG } & \text { Epigallocatechin gallate } \\ \text { ESRD } & \text { End stage renal disease }\end{array}$




$\begin{array}{ll}\text { GO } & \text { Gingival overgrowth } \\ \text { HD } & \text { Hemodialysis } \\ \text { HSV } & \text { Herpes virus simplex } \\ \text { ICAM } & \text { Intercellular adhesion molecule } \\ \text { IL } & \text { Interleukin } \\ \text { MMPs } & \text { Matrix metalloproteinases } \\ \text { NBCs } & \text { Natural bioactive compounds } \\ \text { NF-kB } & \text { Factor-kB } \\ \text { OS } & \text { Oxidative stress } \\ \text { PEW } & \text { Protein-Energy Wasting } \\ \text { RANKL } & \text { Receptor activator of nuclear factor-kB ligand } \\ \text { ROS } & \text { Reactive oxygen species } \\ \text { RRT } & \text { Renal replacement therapy } \\ \text { TNF } & \text { Tumor necrosis factor } \\ \text { VCAM } & \text { Vascular cell adhesion molecule }\end{array}$

\section{References}

1. Peres, M.A.; Macpherson, L.M.D.; Weyant, R.J.; Daly, B.; Venturelli, R.; Mathur, M.R.; Listl, S.; Celeste, R.K.; Guarnizo-Herreno, C.C.; Kearns, C.; et al. Oral diseases: A global public health challenge. Lancet 2019, 394, 249-260. [CrossRef]

2. Zeng, X.J.; Gao, X.J. Prevention and control of oral diseases via "Common Risk Factor Approach". Zhonghua Kou Qiang Yi Xue Za Zhi 2019, 54, 721-726. [CrossRef] [PubMed]

3. Noce, A.; Vidiri, M.F.; Marrone, G.; Moriconi, E.; Bocedi, A.; Capria, A.; Rovella, V.; Ricci, G.; De Lorenzo, A.; Di Daniele, N. Is low-protein diet a possible risk factor of malnutrition in chronic kidney disease patients? Cell Death Discov. 2016, 2, 16026. [CrossRef]

4. Wolf, T.G.; Cagetti, M.G.; Fisher, J.-M.; Seeberger, G.K.; Campus, G. Non-communicable Diseases and Oral Health: An Overview. Front. Oral Health 2021, 2, 725460. [CrossRef]

5. Dorfer, C.; Benz, C.; Aida, J.; Campard, G. The relationship of oral health with general health and NCDs: A brief review. Int. Dent. J. 2017, 67 (Suppl 2), 14-18. [CrossRef] [PubMed]

6. Yonel, Z.; Sharma, P. The Role of the Dental Team in the Prevention of Systemic Disease: The Importance of Considering Oral Health As Part of Overall Health. Prim. Dent. J. 2017, 6, 24-27. [CrossRef] [PubMed]

7. Ide, R.; Hoshuyama, T.; Wilson, D.; Takahashi, K.; Higashi, T. Periodontal disease and incident diabetes: A seven-year study. J. Dent. Res. 2011, 90, 41-46. [CrossRef]

8. Preshaw, P.M.; Alba, A.L.; Herrera, D.; Jepsen, S.; Konstantinidis, A.; Makrilakis, K.; Taylor, R. Periodontitis and diabetes: A two-way relationship. Diabetologia 2012, 55, 21-31. [CrossRef]

9. Kelley, K.W. NIH public access policy. Brain Behav. Immun. 2008, 22, 629. [CrossRef]

10. Kebschull, M.; Demmer, R.T.; Papapanou, P.N. “Gum bug, leave my heart alone!"-Epidemiologic and mechanistic evidence linking periodontal infections and atherosclerosis. J. Dent. Res. 2010, 89, 879-902. [CrossRef]

11. Czesnikiewicz-Guzik, M.; Osmenda, G.; Siedlinski, M.; Nosalski, R.; Pelka, P.; Nowakowski, D.; Wilk, G.; Mikolajczyk, T.P.; Schramm-Luc, A.; Furtak, A.; et al. Causal association between periodontitis and hypertension: Evidence from Mendelian randomization and a randomized controlled trial of non-surgical periodontal therapy. Eur. Heart J. 2019, 40, 3459-3470. [CrossRef] [PubMed]

12. Dominy, S.S.; Lynch, C.; Ermini, F.; Benedyk, M.; Marczyk, A.; Konradi, A.; Nguyen, M.; Haditsch, U.; Raha, D.; Griffin, C.; et al Porphyromonas gingivalis in Alzheimer's disease brains: Evidence for disease causation and treatment with small-molecule inhibitors. Sci. Adv. 2019, 5, eaau3333. [CrossRef]

13. Di Daniele, N.; Di Renzo, L.; Noce, A.; Iacopino, L.; Ferraro, P.M.; Rizzo, M.; Sarlo, F.; Domino, E.; De Lorenzo, A. Effects of Italian Mediterranean organic diet vs. low-protein diet in nephropathic patients according to MTHFR genotypes. J. Nephrol. 2014, 27, 529-536. [CrossRef]

14. Balaji, S.M.; Seeberger, G.K.; Hennedige, O. Burden of oral diseases and noncommunicable diseases: An Asia-Pacific perspective. Indian J. Dent. Res. 2018, 29, 820-829. [CrossRef]

15. Akar, H.; Akar, G.C.; Carrero, J.J.; Stenvinkel, P.; Lindholm, B. Systemic consequences of poor oral health in chronic kidney disease patients. Clin. J. Am. Soc. Nephrol. 2011, 6, 218-226. [CrossRef]

16. Sharma, P.; Fenton, A.; Dias, I.H.K.; Heaton, B.; Brown, C.L.R.; Sidhu, A.; Rahman, M.; Griffiths, H.R.; Cockwell, P.; Ferro, C.J.; et al. Oxidative stress links periodontal inflammation and renal function. J. Clin. Periodontol. 2021, 48, 357-367. [CrossRef]

17. Tadakamadla, J.; Kumar, S.; Mamatha, G.P. Comparative evaluation of oral health status of chronic kidney disease (CKD) patients in various stages and healthy controls. Spec. Care Dentist. 2014, 34, 122-126. [CrossRef] [PubMed]

18. Niculescu, A.G.; Grumezescu, A.M. Natural Compounds for Preventing Ear, Nose, and Throat-Related Oral Infections. Plants 2021, 10, 1847. [CrossRef] 
19. Duan, X.; Chen, X.; Gupta, M.; Seriwatanachai, D.; Xue, H.; Xiong, Q.; Xu, T.; Li, D.; Mo, A.; Tang, X.; et al. Salivary microbiome in patients undergoing hemodialysis and its associations with the duration of the dialysis. BMC Nephrol. 2020, 21, 414. [CrossRef] [PubMed]

20. Hu, J.; Iragavarapu, S.; Nadkarni, G.N.; Huang, R.; Erazo, M.; Bao, X.; Verghese, D.; Coca, S.; Ahmed, M.K.; Peter, I. LocationSpecific Oral Microbiome Possesses Features Associated With CKD. Kidney Int. Rep. 2018, 3, 193-204. [CrossRef] [PubMed]

21. Menks, F. Drawings by frustrated and nonfrustrated four-year-olds. Am. J. Occup. Ther. 1973, 27, 336-338. [PubMed]

22. Liu, R.H. Dietary bioactive compounds and their health implications. J. Food Sci. 2013, 78 (Suppl 1), A18-A25. [CrossRef] [PubMed]

23. Candi, E.; Tesauro, M.; Cardillo, C.; Lena, A.M.; Schinzari, F.; Rodia, G.; Sica, G.; Gentileschi, P.; Rovella, V.; AnnicchiaricoPetruzzelli, M.; et al. Metabolic profiling of visceral adipose tissue from obese subjects with or without metabolic syndrome. Biochem. J. 2018, 475, 1019-1035. [CrossRef]

24. Liu, R.H. Potential synergy of phytochemicals in cancer prevention: Mechanism of action. J. Nutr. 2004, 134, 3479S-3485S [CrossRef]

25. Noce, A.; Bocedi, A.; Campo, M.; Marrone, G.; Di Lauro, M.; Cattani, G.; Di Daniele, N.; Romani, A. A Pilot Study of a Natural Food Supplement as New Possible Therapeutic Approach in Chronic Kidney Disease Patients. Pharmaceuticals 2020, $13,148$. [CrossRef]

26. Karasawa, M.M.G.; Mohan, C. Fruits as Prospective Reserves of bioactive Compounds: A Review. Nat. Prod. Bioprospect. 2018, 8 , 335-346. [CrossRef] [PubMed]

27. Noce, A.; Marrone, G.; Di Lauro, M.; Urciuoli, S.; Pietroboni Zaitseva, A.; Wilson Jones, G.; Di Daniele, N.; Romani, A. Cardiovascular Protection of Nephropathic Male Patients by Oral Food Supplements. Cardiovasc. Ther. 2020, $2020,1807941$. [CrossRef]

28. Noce, A.; Di Lauro, M.; Di Daniele, F.; Pietroboni Zaitseva, A.; Marrone, G.; Borboni, P.; Di Daniele, N. Natural Bioactive Compounds Useful in Clinical Management of Metabolic Syndrome. Nutrients 2021, 13, 630. [CrossRef]

29. Ruospo, M.; Palmer, S.C.; Craig, J.C.; Gentile, G.; Johnson, D.W.; Ford, P.J.; Tonelli, M.; Petruzzi, M.; De Benedittis, M.; Strippoli, G.F. Prevalence and severity of oral disease in adults with chronic kidney disease: A systematic review of observational studies. Nephrol. Dial. Transpl. 2014, 29, 364-375. [CrossRef]

30. Kanjevac, T.; Bijelic, B.; Brajkovic, D.; Vasovic, M.; Stolic, R. Impact of Chronic Kidney Disease Mineral and Bone Disorder on Jaw and Alveolar Bone Metabolism: A Narrative Review. Oral Health Prev. Dent. 2018, 16, 79-85. [CrossRef]

31. Parkar, S.M.; Ajithkrishnan, C.G. Periodontal status in patients undergoing hemodialysis. Indian J. Nephrol. 2012, 22, 246-250. [CrossRef]

32. Noce, A.; Ferrannini, M.; Fabrini, R.; Bocedi, A.; Dessi, M.; Galli, F.; Federici, G.; Palumbo, R.; Di Daniele, N.; Ricci, G. Erythrocyte glutathione transferase: A new biomarker for hemodialysis adequacy, overcoming the Kt/V(urea) dogma? Cell Death Dis. 2012, 3, e377. [CrossRef]

33. Bayraktar, G.; Kurtulus, I.; Kazancioglu, R.; Bayramgurler, I.; Cintan, S.; Bural, C.; Bozfakioglu, S.; Issever, H.; Yildiz, A. Oral health and inflammation in patients with end-stage renal failure. Perit. Dial. Int. 2009, 29, 472-479. [CrossRef] [PubMed]

34. Wahid, A.; Chaudhry, S.; Ehsan, A.; Butt, S.; Ali Khan, A. Bidirectional Relationship between Chronic Kidney Disease \& Periodontal Disease. Pak. J. Med. Sci. 2013, 29, 211-215. [CrossRef] [PubMed]

35. Alamo, S.; Esteve, C.; Pérez, M.G. Dental considerations for the patient with renal disease. J. Clin. Exp. Dent. 2011, 3, e112-e119. [CrossRef]

36. Santaella, N.G.; Maciel, A.P.; Simpione, G.; Santos, P.S. Halitosis, reduced salivary flow and the quality of life in pre-kidney transplantation patients. J. Clin. Exp. Dent. 2020, 12, e1045-e1049. [CrossRef]

37. Chen, W.; Laiho, S.; Vaittinen, O.; Halonen, L.; Ortiz, F.; Forsblom, C.; Groop, P.H.; Lehto, M.; Metsala, M. Biochemical pathways of breath ammonia (NH3) generation in patients with end-stage renal disease undergoing hemodialysis. J. Breath Res. 2016, 10, 036011. [CrossRef] [PubMed]

38. Hanna, R.M.; Ghobry, L.; Wassef, O.; Rhee, C.M.; Kalantar-Zadeh, K. A Practical Approach to Nutrition, Protein-Energy Wasting, Sarcopenia, and Cachexia in Patients with Chronic Kidney Disease. Blood Purif. 2020, 49, 202-211. [CrossRef]

39. Carrero, J.J.; Stenvinkel, P.; Cuppari, L.; Ikizler, T.A.; Kalantar-Zadeh, K.; Kaysen, G.; Mitch, W.E.; Price, S.R.; Wanner, C.; Wang, A.Y.; et al. Etiology of the protein-energy wasting syndrome in chronic kidney disease: A consensus statement from the International Society of Renal Nutrition and Metabolism (ISRNM). J. Ren. Nutr. 2013, 23, 77-90. [CrossRef] [PubMed]

40. Wang, X.H.; Mitch, W.E. Mechanisms of muscle wasting in chronic kidney disease. Nat. Rev. Nephrol. 2014, 10, 504-516. [CrossRef]

41. Den Hoedt, C.H.; Bots, M.L.; Grooteman, M.P.; van der Weerd, N.C.; Penne, E.L.; Mazairac, A.H.; Levesque, R.; Blankestijn, P.J.; Nube, M.J.; ter Wee, P.M.; et al. Clinical predictors of decline in nutritional parameters over time in ESRD. Clin. J. Am. Soc. Nephrol. 2014, 9, 318-325. [CrossRef] [PubMed]

42. Kim, Y.; Molnar, M.Z.; Rattanasompattikul, M.; Hatamizadeh, P.; Benner, D.; Kopple, J.D.; Kovesdy, C.P.; Kalantar-Zadeh, K. Relative contributions of inflammation and inadequate protein intake to hypoalbuminemia in patients on maintenance hemodialysis. Int. Urol. Nephrol. 2013, 45, 215-227. [CrossRef]

43. De Rossi, S.S.; Glick, M. Dental considerations for the patient with renal disease receiving hemodialysis. J. Am. Dent. Assoc. 1996, 127, 211-219. [CrossRef] 
44. Proctor, R.; Kumar, N.; Stein, A.; Moles, D.; Porter, S. Oral and dental aspects of chronic renal failure. J Dent Res 2005, 84, 199-208. [CrossRef]

45. De la Rosa Garcia, E.; Mondragon Padilla, A.; Aranda Romo, S.; Bustamante Ramirez, M.A. Oral mucosa symptoms, signs and lesions, in end stage renal disease and non-end stage renal disease diabetic patients. Med. Oral Patol. Oral Cir. Bucal 2006, 11, E467-E473.

46. Leao, J.C.; Gueiros, L.A.; Segundo, A.V.; Carvalho, A.A.; Barrett, W.; Porter, S.R. Uremic stomatitis in chronic renal failure. Clinics (Sao Paulo) 2005, 60, 259-262. [CrossRef]

47. Davidovich, E.; Davidovits, M.; Eidelman, E.; Schwarz, Z.; Bimstein, E. Pathophysiology, therapy, and oral implications of renal failure in children and adolescents: An update. Pediatr. Dent. 2005, 27, 98-106.

48. Limeira, F.I.R.; Yamauti, M.; Moreira, A.N.; Galdino, T.M.; de Magalhaes, C.S.; Abreu, L.G. Dental caries and developmental defects of enamel in individuals with chronic kidney disease: Systematic review and meta-analysis. Oral Dis. 2019, 25, 1446-1464. [CrossRef] [PubMed]

49. Nikiforuk, G.; Fraser, D. The etiology of enamel hypoplasia: A unifying concept. J. Pediatr. 1981, 98, 888-893. [CrossRef]

50. Bawden, J.W.; Deaton, T.G.; Crenshaw, M.A. The effects of parathyroid hormone, calcitonin, and vitamin D metabolites on calcium transport in the secretory rat enamel organ. J. Dent. Res. 1983, 62, 952-955. [CrossRef]

51. Foster, B.L.; Nociti, F.H., Jr.; Somerman, M.J. The rachitic tooth. Endocr. Rev. 2014, 35, 1-34. [CrossRef] [PubMed]

52. Jover Cervero, A.; Bagan, J.V.; Jimenez Soriano, Y.; Poveda Roda, R. Dental management in renal failure: Patients on dialysis. Med. Oral Patol. Oral Cir. Bucal 2008, 13, E419-E426. [PubMed]

53. Kerr, A.R. Update on renal disease for the dental practitioner. Oral Surg. Oral Med. Oral Pathol. Oral Radiol. Endod. 2001, 92, 9-16. [CrossRef] [PubMed]

54. Tanasiewicz, M.; Hildebrandt, T.; Obersztyn, I. Xerostomia of Various Etiologies: A Review of the Literature. Adv. Clin. Exp. Med. 2016, 25, 199-206. [CrossRef] [PubMed]

55. Seymour, R.A.; Thomason, J.M.; Nolan, A. Oral lesions in organ transplant patients. J. Oral Pathol. Med. 1997, 26, 297-304. [CrossRef]

56. Marshall, R.I.; Bartold, P.M. Medication induced gingival overgrowth. Oral Dis. 1998, 4, 130-151. [CrossRef]

57. Paraskevas, S.; Huizinga, J.D.; Loos, B.G. A systematic review and meta-analyses on C-reactive protein in relation to periodontitis. J. Clin. Periodontol. 2008, 35, 277-290. [CrossRef]

58. Bastos, J.A.; Diniz, C.G.; Bastos, M.G.; Vilela, E.M.; Silva, V.L.; Chaoubah, A.; Souza-Costa, D.C.; Andrade, L.C. Identification of periodontal pathogens and severity of periodontitis in patients with and without chronic kidney disease. Arch. Oral Biol. 2011, 56, 804-811. [CrossRef] [PubMed]

59. Kitamura, M.; Mochizuki, Y.; Miyata, Y.; Obata, Y.; Mitsunari, K.; Matsuo, T.; Ohba, K.; Mukae, H.; Yoshimura, A.; Nishino, T.; et al. Pathological Characteristics of Periodontal Disease in Patients with Chronic Kidney Disease and Kidney Transplantation. Int. J. Mol. Sci. 2019, 20, 3413. [CrossRef]

60. Tonetti, M.S.; D'Aiuto, F.; Nibali, L.; Donald, A.; Storry, C.; Parkar, M.; Suvan, J.; Hingorani, A.D.; Vallance, P.; Deanfield, J. Treatment of periodontitis and endothelial function. N. Engl. J. Med. 2007, 356, 911-920. [CrossRef]

61. Socransky, S.S.; Haffajee, A.D.; Cugini, M.A.; Smith, C.; Kent, R.L., Jr. Microbial complexes in subgingival plaque. J. Clin. Periodontol. 1998, 25, 134-144. [CrossRef]

62. Griffen, A.L.; Beall, C.J.; Campbell, J.H.; Firestone, N.D.; Kumar, P.S.; Yang, Z.K.; Podar, M.; Leys, E.J. Distinct and complex bacterial profiles in human periodontitis and health revealed by $16 \mathrm{~S}$ pyrosequencing. ISME J. 2012, 6, 1176-1185. [CrossRef]

63. Abusleme, L.; Dupuy, A.K.; Dutzan, N.; Silva, N.; Burleson, J.A.; Strausbaugh, L.D.; Gamonal, J.; Diaz, P.I. The subgingival microbiome in health and periodontitis and its relationship with community biomass and inflammation. ISME J. 2013, 7, 1016-1025. [CrossRef]

64. Perez-Chaparro, P.J.; Goncalves, C.; Figueiredo, L.C.; Faveri, M.; Lobao, E.; Tamashiro, N.; Duarte, P.; Feres, M. Newly identified pathogens associated with periodontitis: A systematic review. J. Dent. Res. 2014, 93, 846-858. [CrossRef]

65. Yletyinen, J.; Perry, G.L.W.; Stahlmann-Brown, P.; Pech, R.; Tylianakis, J.M. Multiple social network influences can generate unexpected environmental outcomes. Sci. Rep. 2021, 11, 9768. [CrossRef] [PubMed]

66. Gimbrone, M.A., Jr.; Garcia-Cardena, G. Endothelial Cell Dysfunction and the Pathobiology of Atherosclerosis. Circ. Res. 2016, 118, 620-636. [CrossRef] [PubMed]

67. Noce, A.; Canale, M.P.; Capria, A.; Rovella, V.; Tesauro, M.; Splendiani, G.; Annicchiarico-Petruzzelli, M.; Manzuoli, M.; Simonetti, G.; Di Daniele, N. Coronary artery calcifications predict long term cardiovascular events in non diabetic Caucasian hemodialysis patients. Aging (Albany NY) 2015, 7, 269-279. [CrossRef] [PubMed]

68. Kanzaki, H.; Wada, S.; Narimiya, T.; Yamaguchi, Y.; Katsumata, Y.; Itohiya, K.; Fukaya, S.; Miyamoto, Y.; Nakamura, Y. Pathways that Regulate ROS Scavenging Enzymes, and Their Role in Defense Against Tissue Destruction in Periodontitis. Front. Physiol. 2017, 8, 351. [CrossRef] [PubMed]

69. Tomofuji, T.; Ekuni, D.; Irie, K.; Azuma, T.; Tamaki, N.; Maruyama, T.; Yamamoto, T.; Watanabe, T.; Morita, M. Relationships between periodontal inflammation, lipid peroxide and oxidative damage of multiple organs in rats. Biomed. Res. 2011, 32, 343-349. [CrossRef] [PubMed]

70. Cochrane, R.; Bal, S. The drinking habits of Sikh, Hindu, Muslim and white men in the West Midlands: A community survey. Br. J. Addict. 1990, 85, 759-769. [CrossRef] 
71. Sakagami, H.; Tomomura, M. Dental Application of Natural Products. Medicines 2018, 5, 21. [CrossRef] [PubMed]

72. Noce, A.; Marrone, G.; Urciuoli, S.; Di Daniele, F.; Di Lauro, M.; Pietroboni Zaitseva, A.; Di Daniele, N.; Romani, A. Usefulness of Extra Virgin Olive Oil Minor Polar Compounds in the Management of Chronic Kidney Disease Patients. Nutrients 2021, 13, 581. [CrossRef] [PubMed]

73. Karygianni, L.; Al-Ahmad, A.; Argyropoulou, A.; Hellwig, E.; Anderson, A.C.; Skaltsounis, A.L. Natural Antimicrobials and Oral Microorganisms: A Systematic Review on Herbal Interventions for the Eradication of Multispecies Oral Biofilms. Front. Microbiol. 2015, 6, 1529. [CrossRef] [PubMed]

74. Hoglund, K.B.; Barnett, B.K.; Watson, S.A.; Melgarejo, M.B.; Kang, Y. Activity of bioactive garlic compounds on the oral microbiome: A literature review. Gen. Dent. 2020, 68, 27-33.

75. Shetty, S.; Thomas, B.; Shetty, V.; Bhandary, R.; Shetty, R.M. An in-vitro evaluation of the efficacy of garlic extract as an antimicrobial agent on periodontal pathogens: A microbiological study. Ayu 2013, 34, 445-451. [CrossRef]

76. Narotzki, B.; Reznick, A.Z.; Aizenbud, D.; Levy, Y. Green tea: A promising natural product in oral health. Arch. Oral Biol. 2012, 57, 429-435. [CrossRef]

77. Chinnam, N.; Dadi, P.K.; Sabri, S.A.; Ahmad, M.; Kabir, M.A.; Ahmad, Z. Dietary bioflavonoids inhibit Escherichia coli ATP synthase in a differential manner. Int. J. Biol. Macromol. 2010, 46, 478-486. [CrossRef]

78. Reygaert, W.C. The antimicrobial possibilities of green tea. Front. Microbiol. 2014, 5, 434. [CrossRef]

79. Lakshmi, A.; Vishnurekha, C.; Baghkomeh, P.N. Effect of theobromine in antimicrobial activity: An in vitro study. Dent. Res. J. (Isfahan) 2019, 16, 76-80. [CrossRef]

80. Ooshima, T.; Osaka, Y.; Sasaki, H.; Osawa, K.; Yasuda, H.; Matsumura, M.; Sobue, S.; Matsumoto, M. Caries inhibitory activity of cacao bean husk extract in in-vitro and animal experiments. Arch. Oral. Biol. 2000, 45, 639-645. [CrossRef]

81. Ferrazzano, G.F.; Amato, I.; Ingenito, A.; De Natale, A.; Pollio, A. Anti-cariogenic effects of polyphenols from plant stimulant beverages (cocoa, coffee, tea). Fitoterapia 2009, 80, 255-262. [CrossRef] [PubMed]

82. Tian, B.; Hua, Y.J.; Ma, X.Q.; Wang, G.L. Relationship between antibacterial activity of aloe and its anthaquinone compounds. Zhongguo Zhong Yao Za Zhi 2003, 28, 1034-1037. [PubMed]

83. Al-Maweri, S.A.; Nassani, M.Z.; Alaizari, N.; Kalakonda, B.; Al-Shamiri, H.M.; Alhajj, M.N.; Al-Soneidar, W.A.; Alahmary, A.W. Efficacy of aloe vera mouthwash versus chlorhexidine on plaque and gingivitis: A systematic review. Int. J. Dent. Hyg. 2020, 18, 44-51. [CrossRef]

84. Franco, R.; Basilicata, M.; Terenzi, A.; Vergou, N.; Bollero, P. The effects of aloe vera on periodontal health. Eur. J. Mol. Clin. Med. 2021, 7, 2865-2870.

85. Palaska, I.; Papathanasiou, E.; Theoharides, T.C. Use of polyphenols in periodontal inflammation. Eur. J. Pharmacol. 2013, 720, 77-83. [CrossRef]

86. Bodet, C.; Chandad, F.; Grenier, D. Anti-inflammatory activity of a high-molecular-weight cranberry fraction on macrophages stimulated by lipopolysaccharides from periodontopathogens. J. Dent. Res. 2006, 85, 235-239. [CrossRef]

87. Bodet, C.; Chandad, F.; Grenier, D. Cranberry components inhibit interleukin-6, interleukin-8, and prostaglandin E production by lipopolysaccharide-activated gingival fibroblasts. Eur. J. Oral Sci. 2007, 115, 64-70. [CrossRef]

88. La, V.D.; Howell, A.B.; Grenier, D. Cranberry proanthocyanidins inhibit MMP production and activity. J. Dent. Res. 2009, 88, 627-632. [CrossRef]

89. Bodet, C.; Grenier, D.; Chandad, F.; Ofek, I.; Steinberg, D.; Weiss, E.I. Potential oral health benefits of cranberry. Crit. Rev. Food Sci. Nutr. 2008, 48, 672-680. [CrossRef]

90. Casili, G.; Ardizzone, A.; Lanza, M.; Gugliandolo, E.; Portelli, M.; Militi, A.; Cuzzocrea, S.; Esposito, E.; Paterniti, I. Treatment with Luteolin Improves Lipopolysaccharide-Induced Periodontal Diseases in Rats. Biomedicines 2020, 8, 442. [CrossRef]

91. Balci Yuce, H.; Toker, H.; Yildirim, A.; Tekin, M.B.; Gevrek, F.; Altunbas, N. The effect of luteolin in prevention of periodontal disease in Wistar rats. J. Periodontol. 2019, 90, 1481-1489. [CrossRef]

92. Gutierrez-Venegas, G.; Contreras-Sanchez, A. Luteolin and fisetin inhibit the effects of lipopolysaccharide obtained from Porphyromonas gingivalis in human gingival fibroblasts. Mol. Biol. Rep. 2013, 40, 477-485. [CrossRef]

93. Nair, M.P.; Mahajan, S.; Reynolds, J.L.; Aalinkeel, R.; Nair, H.; Schwartz, S.A.; Kandaswami, C. The flavonoid quercetin inhibits proinflammatory cytokine (tumor necrosis factor alpha) gene expression in normal peripheral blood mononuclear cells via modulation of the NF-kappa beta system. Clin. Vaccine Immunol. 2006, 13, 319-328. [CrossRef]

94. Napimoga, M.H.; Clemente-Napimoga, J.T.; Macedo, C.G.; Freitas, F.F.; Stipp, R.N.; Pinho-Ribeiro, F.A.; Casagrande, R.; Verri, W.A., Jr. Quercetin inhibits inflammatory bone resorption in a mouse periodontitis model. J. Nat. Prod. 2013, 76, 2316-2321. [CrossRef]

95. Cao, J.H.; Xue, R.; He, B. Quercetin protects oral mucosal keratinocytes against lipopolysaccharide-induced inflammatory toxicity by suppressing the AKT/AMPK/mTOR pathway. Immunopharmacol. Immunotoxicol. 2021, 43, 519-526. [CrossRef] [PubMed]

96. Nagpal, M.; Sood, S. Role of curcumin in systemic and oral health: An overview. J. Nat. Sci. Biol. Med. 2013, 4, 3-7. [CrossRef]

97. Pulikkotil, S.J.; Nath, S. Effects of curcumin on crevicular levels of IL-1beta and CCL28 in experimental gingivitis. Aust. Dent. J. 2015, 60, 317-327. [CrossRef] [PubMed]

98. Isola, G. Current Evidence of Natural Agents in Oral and Periodontal Health. Nutrients 2020, 12, 585. [CrossRef] [PubMed] 
99. Vo, T.T.T.; Chu, P.M.; Tuan, V.P.; Te, J.S.; Lee, I.T. The Promising Role of Antioxidant Phytochemicals in the Prevention and Treatment of Periodontal Disease via the Inhibition of Oxidative Stress Pathways: Updated Insights. Antioxidants 2020, 9, 1211. [CrossRef]

100. Nugala, B.; Namasi, A.; Emmadi, P.; Krishna, P.M. Role of green tea as an antioxidant in periodontal disease: The Asian paradox. J. Indian Soc. Periodontol. 2012, 16, 313-316. [CrossRef]

101. Hrishi, T.S.; Kundapur, P.P.; Naha, A.; Thomas, B.S.; Kamath, S.; Bhat, G.S. Effect of adjunctive use of green tea dentifrice in periodontitis patients-A Randomized Controlled Pilot Study. Int. J. Dent. Hyg. 2016, 14, 178-183. [CrossRef] [PubMed]

102. Bhattarai, G.; Poudel, S.B.; Kook, S.H.; Lee, J.C. Anti-inflammatory, anti-osteoclastic, and antioxidant activities of genistein protect against alveolar bone loss and periodontal tissue degradation in a mouse model of periodontitis. J. Biomed. Mater. Res. A 2017, 105, 2510-2521. [CrossRef]

103. Belludi, S.A.; Verma, S.; Banthia, R.; Bhusari, P.; Parwani, S.; Kedia, S.; Saiprasad, S.V. Effect of lycopene in the treatment of periodontal disease: A clinical study. J. Contemp. Dent. Pract. 2013, 14, 1054-1059. [CrossRef] [PubMed]

104. Tripathi, P.; Blaggana, V.; Upadhyay, P.; Jindal, M.; Gupta, S.; Nishat, S. Antioxidant therapy (lycopene and green tea extract) in periodontal disease: A promising paradigm. J. Indian Soc. Periodontol. 2019, 23, 25-30. [CrossRef]

105. Andrade, E.F.; Orlando, D.R.; Araujo, A.M.S.; de Andrade, J.; Azzi, D.V.; de Lima, R.R.; Lobo-Junior, A.R.; Pereira, L.J. Can Resveratrol Treatment Control the Progression of Induced Periodontal Disease? A Systematic Review and Meta-Analysis of Preclinical Studies. Nutrients 2019, 11, 953. [CrossRef]

106. Mokni, M.; Elkahoui, S.; Limam, F.; Amri, M.; Aouani, E. Effect of resveratrol on antioxidant enzyme activities in the brain of healthy rat. Neurochem. Res. 2007, 32, 981-987. [CrossRef]

107. Mileo, A.M.; Miccadei, S. Polyphenols as Modulator of Oxidative Stress in Cancer Disease: New Therapeutic Strategies. Oxid. Med. Cell Longev. 2016, 2016, 6475624. [CrossRef]

108. Zhou, Y.; Zheng, J.; Li, Y.; Xu, D.P.; Li, S.; Chen, Y.M.; Li, H.B. Natural Polyphenols for Prevention and Treatment of Cancer. Nutrients 2016, 8, 515. [CrossRef]

109. Ding, Y.; Yao, H.; Yao, Y.; Fai, L.Y.; Zhang, Z. Protection of dietary polyphenols against oral cancer. Nutrients 2013, 5, $2173-2191$. [CrossRef]

110. Belobrov, S.; Seers, C.; Reynolds, E.; Cirillo, N.; McCullough, M. Functional and molecular effects of a green tea constituent on oral cancer cells. J. Oral Pathol. Med. 2019, 48, 604-610. [CrossRef] [PubMed]

111. Dasari, S.; Tchounwou, P.B. Cisplatin in cancer therapy: Molecular mechanisms of action. Eur. J. Pharmacol. 2014, 740, 364-378. [CrossRef]

112. Pan, H.; Chen, J.; Shen, K.; Wang, X.; Wang, P.; Fu, G.; Meng, H.; Wang, Y.; Jin, B. Mitochondrial modulation by Epigallocatechin 3-Gallate ameliorates cisplatin induced renal injury through decreasing oxidative/nitrative stress, inflammation and NF-kB in mice. PLoS ONE 2015, 10, e0124775. [CrossRef]

113. Vanni, G.; Pellicciaro, M.; Materazzo, M.; Bruno, V.; Oldani, C.; Pistolese, C.A.; Buonomo, C.; Caspi, J.; Gualtieri, P.; Chiaravalloti, A.; et al. Lockdown of Breast Cancer Screening for COVID-19: Possible Scenario. In Vivo 2020, 34, 3047-3053. [CrossRef]

114. Vanni, G.; Tazzioli, G.; Pellicciaro, M.; Materazzo, M.; Paolo, O.; Cattadori, F.; Combi, F.; Papi, S.; Pistolese, C.A.; Cotesta, M.; et al. Delay in Breast Cancer Treatments During the First COVID-19 Lockdown. A Multicentric Analysis of 432 Patients. Anticancer Res. 2020, 40, 7119-7125. [CrossRef]

115. Freires, I.A.; Santaella, G.M.; de Cassia Orlandi Sardi, J.; Rosalen, P.L. The alveolar bone protective effects of natural products: A systematic review. Arch. Oral Biol. 2018, 87, 196-203. [CrossRef] [PubMed]

116. Sezer, U.; Kara, M.I.; Erciyas, K.; Ozdemir, H.; Ustun, K.; Ozer, H.; Goze, F. Protective effects of Ginkgo biloba extract on ligature-induced periodontitis in rats. Acta Odontol. Scand. 2013, 71, 38-44. [CrossRef]

117. Lucinda, L.M.F.; Aarestrup, B.J.V.; Reboredo, M.M.; Pains, T.D.A.; Chaves, R.Z.; Reis, J.E.P.; Louzada, M.J.Q.; Guerra, M.O. Evaluation of the anti-osteoporotic effect of Ginkgo biloba L. in Wistar rats with glucocorticoid-induced-osteoporosis by bone densitometry using dual-energy x-ray absorptiometry (DEXA) and mechanical testing. An. Acad. Bras. Cienc. 2017, 89, $2833-2841$. [CrossRef] [PubMed]

118. Horii, H.; Suzuki, R.; Sakagami, H.; Tomomura, M.; Tomomura, A.; Shirataki, Y. New biological activities of Rhinacanthins from the root of Rhinacanthus nasutus. Anticancer Res. 2013, 33, 453-459. [PubMed]

119. Aral, C.A.; Kesim, S.; Greenwell, H.; Kara, M.; Cetin, A.; Yakan, B. Alveolar bone protective and hypoglycemic effects of systemic propolis treatment in experimental periodontitis and diabetes mellitus. J. Med. Food 2015, 18, 195-201. [CrossRef] [PubMed]

120. Toker, H.; Ozan, F.; Ozer, H.; Ozdemir, H.; Eren, K.; Yeler, H. A morphometric and histopathologic evaluation of the effects of propolis on alveolar bone loss in experimental periodontitis in rats. J. Periodontol. 2008, 79, 1089-1094. [CrossRef]

121. Romani, A.; Campo, M.; Urciuoli, S.; Marrone, G.; Noce, A.; Bernini, R. An Industrial and Sustainable Platform for the Production of Bioactive Micronized Powders and Extracts Enriched in Polyphenols From Olea europaea L. and Vitis vinifera L. Wastes. Front. Nutr. 2020, 7, 120. [CrossRef] [PubMed]

122. Noce, A.; Di Daniele, F.; Campo, M.; Di Lauro, M.; Pietroboni Zaitseva, A.; Di Daniele, N.; Marrone, G.; Romani, A. Effect of Hydrolysable Tannins and Anthocyanins on Recurrent Urinary Tract Infections in Nephropathic Patients: Preliminary Data. Nutrients 2021, 13, 591. [CrossRef] [PubMed] 